\title{
Workshop Pangan Jajanan Anak Sekolah (PJAS) dan Inovasi Sarapan Sehat untuk Anak Usia Sekolah
}

\author{
Siti Rahmatul Aini', Iman Surya Pratama1, Agus Dwi Ananto', Luh Putu Gina Sri Budiani1
}

${ }^{1}$ Farmasi, Fakultas Kedokteran, Universitas Mataram, Mataram, Indonesia.

\section{Article Info}

Received : 13-03-2020

Revised : 29-04-2020

Accepted: 29-04-2020

\begin{abstract}
Nutritious and safe intake is a prerequisite for the growth and development of school-age children. Poor breakfast habits and snacks for school children that do not meet the requirements contribute significantly to the nutritional problems of school-age children. This is one of the priority health problems. Low achievement in the implementation of school children's nutrition programs has led to healthy breakfast and snack innovations workshops at one of the elementary schools in Sekarbela sub-district, Mataram city. The workshop participants included 50 people consisting of school-age children, parents, teachers, and canteen vendors. The workshop was guided by a nutritionist, and he explained the selection of nutritional intake, both through breakfast and snack. Also, participants were trained to practice a variety of healthy breakfast innovation menus. After the workshop, participants were able to practice and be actively involved in making a healthy breakfast innovation menu. The response of participants to the menu is quite good. After mentoring by a nutritionist, parents and teachers can solve the problems encountered. Cafeteria vendors get input regarding snacks supply after expert review. This workshop has been going well and has produced the results as targeted.
\end{abstract}

Keywords: PJAS, healthy breakfast, workshop, school-age children.

Citation: $\quad$ Aini, S. R., Pratama, I. S., Ananto, A. D., \& Budiani, L. P. G. S. (2020). Workshop Pangan Jajanan Anak Sekolah (PJAS) dan inovasi sarapan sehat untuk anak usia sekolah. INDRA Jurnal Pengabdian kepada Masyarakat, 1(1), 15-19.

\section{Pendahuluan}

Peningkatan status gizi ibu dan anak merupakan salah satu sasaran prioritas Rencana Pembangunan Jangka Menengah Nasional 2015-2019. Isu gizi masih menjadi sasaran strategis pembangunan kesehatan mengingat hingga tahun 2013 prevalensi gizi buruk di berbagai daerah di Indonesia masih melebihi prevalensi nasional sebesar $19,6 \%$ sebagaimana yang disajikan pada Gambar 1. Di sisi lain beban ganda gizi mengalami peningkatan dan menjadi isu strategis baru (Kementerian Kesehatan RI, 2015).

Tak terkecuali provinsi Nusa Tenggara Barat (NTB), prevalensi gizi buruk dan retardasi tumbuh linier berada di atas prevalensi nasional. Pada awal tahun 2015 angka prevalensi gizi buruk sebesar 25,7\%. Kunjungan kerja Menteri Pemberdayaan Perempuan dan Perlindungan Anak, Yohana Yambise, pada bulan
Oktober 2015 ke Puskesmas Karang Taliwang di Kota Mataram menghasilkan temuan 2 kasus pasien gizi buruk, dari total 17 kasus dalam tahun 2015 (Nirkomala, 2015).

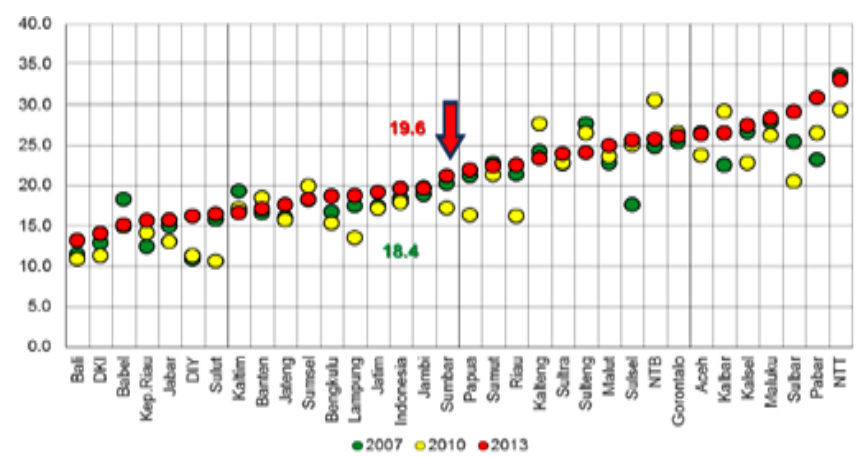

Gambar 1. Prevalensi gizi kurang tahun 20072013 (Sugihantono, 2014) 
Penyebab masalah gizi di provinsi NTB jika dianalisis menurut klasifikasi UNICEF 1998 bertumpu pada penyebab tidak langsung berupa aksesibilitas pangan dan pola asuh yang salah sebagaimana disajikan pada Gambar 2. Skor Pola Pangan Harapan provinsi NTB tahun 2011 dengan nilai 76 menunjukkan keragaman mutu gizi dan asupan konsumsi yang tergolong tidak seimbang. Perceraian, ibu dengan pekerjaan sebagai tenaga kerja asing (TKW) turut memberikan sumbangsih pola asuh yang salah.

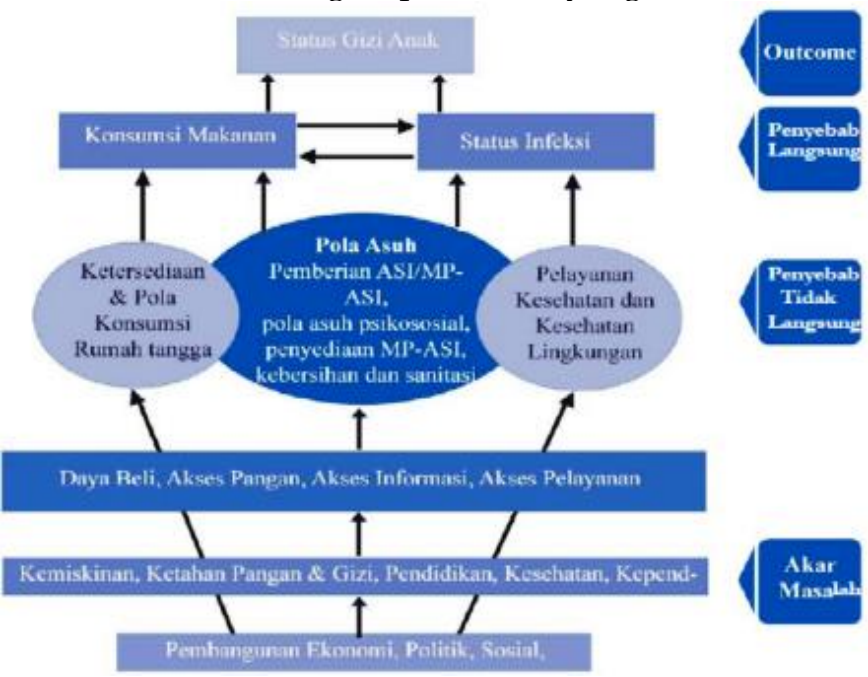

Gambar 2. Kerangka pikir masalah gizi (Pemerintah Provinsi NTB, 2012)

Masalah gizi pada usia anak sekolah patut menjadi fokus karena berpengaruh pada produktivitas di masa dewasa. Asupan gizi yang seimbang pada anak usia sekolah diperoleh diantaranya dari sarapan. Simpulan dari 100 penelitian berbasis bukti yang telah dipublikasi menunjukkan dasar saintifik bahwa program sarapan yang dilakukan di sekolah lebih efektif membuat anak siap untuk belajar, mendapat asupan makanan bernutrisi dan memacu anak untuk lebih sehat baik secara fisik maupun emosional (Brown, Beardslee, \& Prothrow-Stith, 2008).

Sarapan juga mampu menurunkan beban ganda gizi melalui penurunan angka jajan tidak sehat dan sindroma metabolik (Kementerian Kesehatan RI, 2014). Meskipun sarapan sangat bermanfaat, prevalensi anak dan remaja yang tidak biasa sarapan bervariasi sebesar $16,9-59 \%$ dengan $44,6 \%$ anak usia sekolah yang sarapan berkualitas rendah (Hardinsyah, 2013). Kualitas sarapan yang rendah menyebabkan asupan anak sekolah tergolong kriteria non-B2SA (Beragam, Bergizi, Seimbang, dan Aman).

Pangan jajanan menjadi alternatif sumber asupan bagi anak sekolah. Survey Pangan Jajanan Anak Sekolah Badan Pengawas Obat dan Makanan (PJAS-BPOM) pada tahun 2009 menunjukkan bahwa pangan jajanan berkontribusi dalam menyumbang $31,1 \%$ energi dan
27,4\% protein dari konsumsi pangan harian. Meskipun demikian aspek keamanan PJAS masih belum sepenuhnya terpenuhi baik dari aspek kimia dan mikrobiologi. Meskipun persentase PJAS mengandung bahan berbahaya telah turun dari $30-45 \%$ pada tahun 2011 menjadi di bawah 9,5\% pada tahun 2014, aspek keamanan PJAS masih perlu diperhatikan.

Pemerintah telah melakukan beberapa upaya lintas sektor untuk mengatasi permasalahan gizi yang diakibatkan oleh kebiasaaan buruk sarapan dan PJAS yang tidak memenuhi syarat. Pekan Sarapan Nasional yang diperingati pada tanggal 14-20 Februari sebagai salah satu momentum untuk menggerakan kebiasaan sarapan sehat. Ketua Penggerak Tim PKK Provinsi NTB Erica Zainul Majdi pada bulan Desember 2015 mendorong agar orangtua lebih berinovasi menyiapkan makanan anak dari rumah misalnya dengan memanfaatkan ubi, jagung yang dinilai memiliki aspek higienisitas, biaya dan keamanan dibandingkan pangan jajanan yang berwarna-warni namun tidak aman.

Aksi nasional PJAS dicetuskan pemerintah dalam rangka menggerakkan kemandirian sekolah dasar untuk menjaga keamanan dan mutu PJAS. Pada bulan Oktober 2015 Gubernur NTB TGH Muhammad Zainul Majdi mengkampanyekan bersama kepala BPOM mengenai kerjasama lintas sektor mutu, keamanan dan gizi. Indikator kinerja utama aksi nasional pada tahun 2014 terdiri atas persentase PJAS yang memenuhi syarat sebesar 90\% dan jumlah cakupan Sekolah Dasar/ Madrasah Ibtidaiyah (SD/MI) yang diintervensi diantaranya sebesar 180 ribu SD/MI. Cakupan SD/MI yang telah mendapatkan intervensi hingga awal tahun 2015 baru sekitar 16.990 SD/MI. Adapun Pendidikan Anak Usia Dini (PAUD) yang mendapatkan intervensi baru sekitar 10 PAUD di kota Mataram hingga akhir tahun 2015.

\section{Metode}

Pendekatan yang digunakan dalam kegiatan penyuluhan berupa kombinasi pola pembimbingan dan pola penyelesaian masalah. Kegiatan dimulai dengan penyuluhan ahli gizi mengenai urgensi sarapan sehat dan diskusi sebagai bentuk penyelesaian masalah yang dihadapi oleh sasaran program. Sebagai aplikasi praktis dari penyuluhan inovasi sarapan sehat, peserta dibimbing oleh tim peneliti sebagai pelatih untuk mendemonstrasikan menu sarapan sehat. Hasil inovasi tersebut kemudian dievaluasi secara sensoris oleh seluruh sasaran dan peserta didik. Peserta yang berpartisipasi dalam demonstrasi pembuatan sarapan sehat ini diberikan penghargaan berupa kenangkenangan oleh panitia penyelenggara. 


\section{Hasil dan Pembahasan}

Kegiatan pengabdian dilaksanakan pada tanggal 23 Januari 2016 di MI Nurul Islam Sekarbela Kecamatan Sekarbela, Kota Mataram. Lokasi kegiatan dipilih sebagai salah satu prototipe MI di Kota Mataram yang memiliki kemudahan akses, sasaran program, dan perizinan, disamping belum pernah menyelenggarakan workshop. Pelaksanaan acara dipilih pada hari Sabtu sehingga memudahkan keterlibatan orang tua siswa dan tidak mengganggu proses belajar-mengajar siswa, setelah sebelumnya berkoordinasi dengan pihak sekolah. Durasi kegiatan selama 4 jam (dimulai pukul 08.00-12.00 WITA).

Peserta kegiatan berjumlah 49 orang sesuai jumlah sasaran yang ditargetkan sebanyak 50 orang dengan rincian 11 orang guru MI, 11 orang wali murid, 3 orang penyedia PJAS, dan 24 orang siswa MI. Kegiatan terdiri atas dua sesi, yaitu penyuluhan oleh ahli gizi dan inovasi sarapan sehat. Sesi penyuluhan dilakukan oleh narasumber ahli gizi selama dua jam dengan memberikan informasi berupa video urgensi sarapan sehat dan contoh visual PJAS yang memenuhi syarat sebagaimana yang disajikan dalam Gambar 3. Media yang digunakan cukup menarik disertai pembahasan yang interaktif antara narasumber dan sasaran sehingga tetap mempertahankan perhatian dalam sesi tersebut.

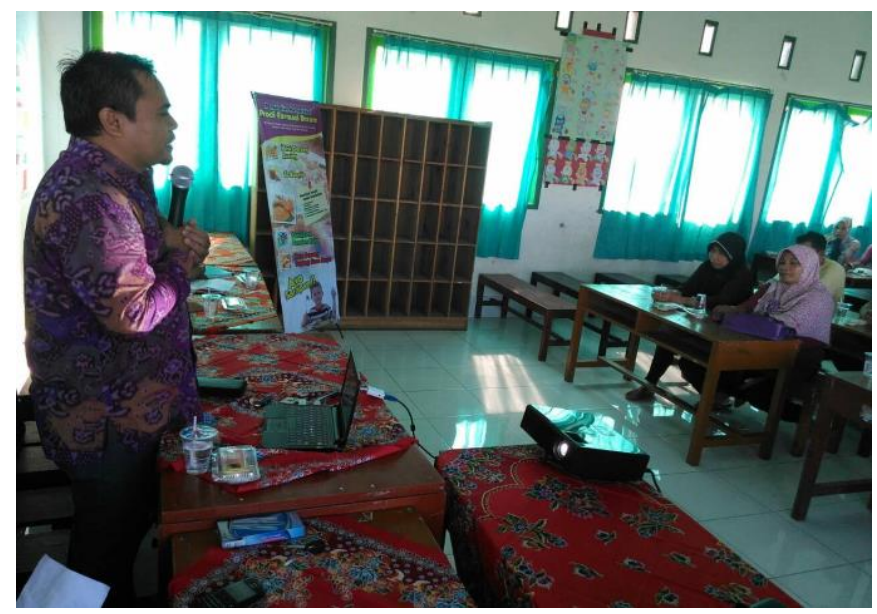

Gambar 3. Sesi penyuluhan PJAS dan sarapan sehat oleh ahli gizi

Presentasi dilanjutkan dengan diskusi mengenai permasalahan sarapan dan PJAS. Isi materi diskusi terkait dengan kriteria pemilihan pewarna makanan yang baik, MSG dan substituennya sebagai bahan tambahan pangan, interaksi antara buah-buahan dengan penyakit, dan konsumsi mie instan. Ditinjau dari ketercapaian materi dan tujuan, materi telah disampaikan dengan bahasa yang dimengerti oleh sasaran program dilihat secara visual dari ekspresi dan keaktifan peserta.
Untuk memastikan penyediaan PJAS yang baik sekaligus memenuhi permohonan pihak MI, tim pengabdi bersama narasumber mengunjungi kantin yang berada di dalam lingkungan sekolah (Gambar 4). Penyedia PJAS juga berada di luar lingkungan sekolah namun dengan jumlah yang tidak signifikan. Akses peserta didik untuk keluar lingkungan sekolah juga dibatasi dengan adanya pintu gerbang yang dijaga oleh penjaga sekolah.

Hasil peninjauan menunjukkan bahwa kantin masih dalam pengembangan sehingga belum optimal dalam menyediakan PJAS yang memenuhi syarat. Hal ini dilihat dari aspek terdapat PJAS dengan waktu kadaluwarsa cepat, bahan tambahan perisa yang terlalu banyak, dan bangunan yang belum permanen serta berlantaikan tanah.

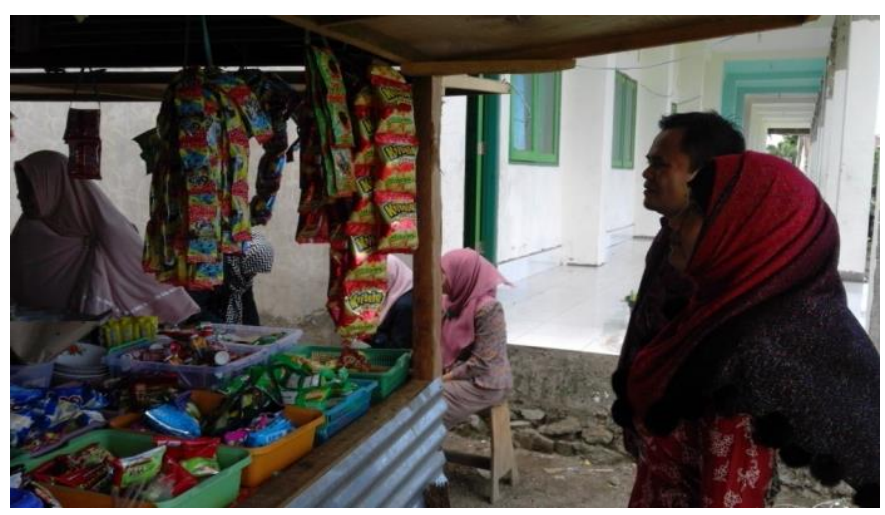

Gambar 4. Peninjauan kantin sekolah oleh tim pengabdian

Sesi pembuatan inovasi sarapan sehat dipandu oleh salah satu anggota dari tim pengabdi sebagaimana yang diilustrasikan dalam Gambar 5. Sasaran program baik guru dan orang tua terlibat aktif dalam pembuatan menu inovasi sarapan sehat. Menu inovasi disajikan pada Tabel 1.

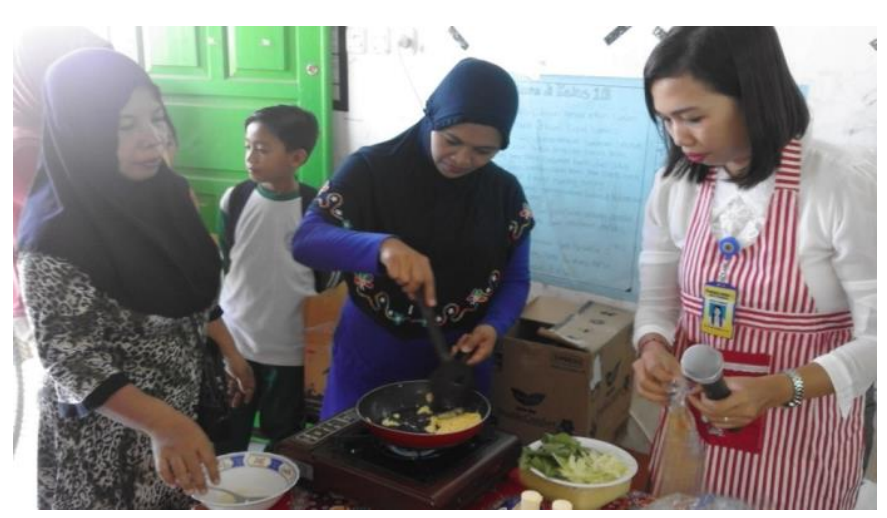

Gambar 5. Kegiatan pembimbingan demonstrasi pembuatan sarapan sehat 
Tabel 1. Resep inovasi menu sarapan sehat

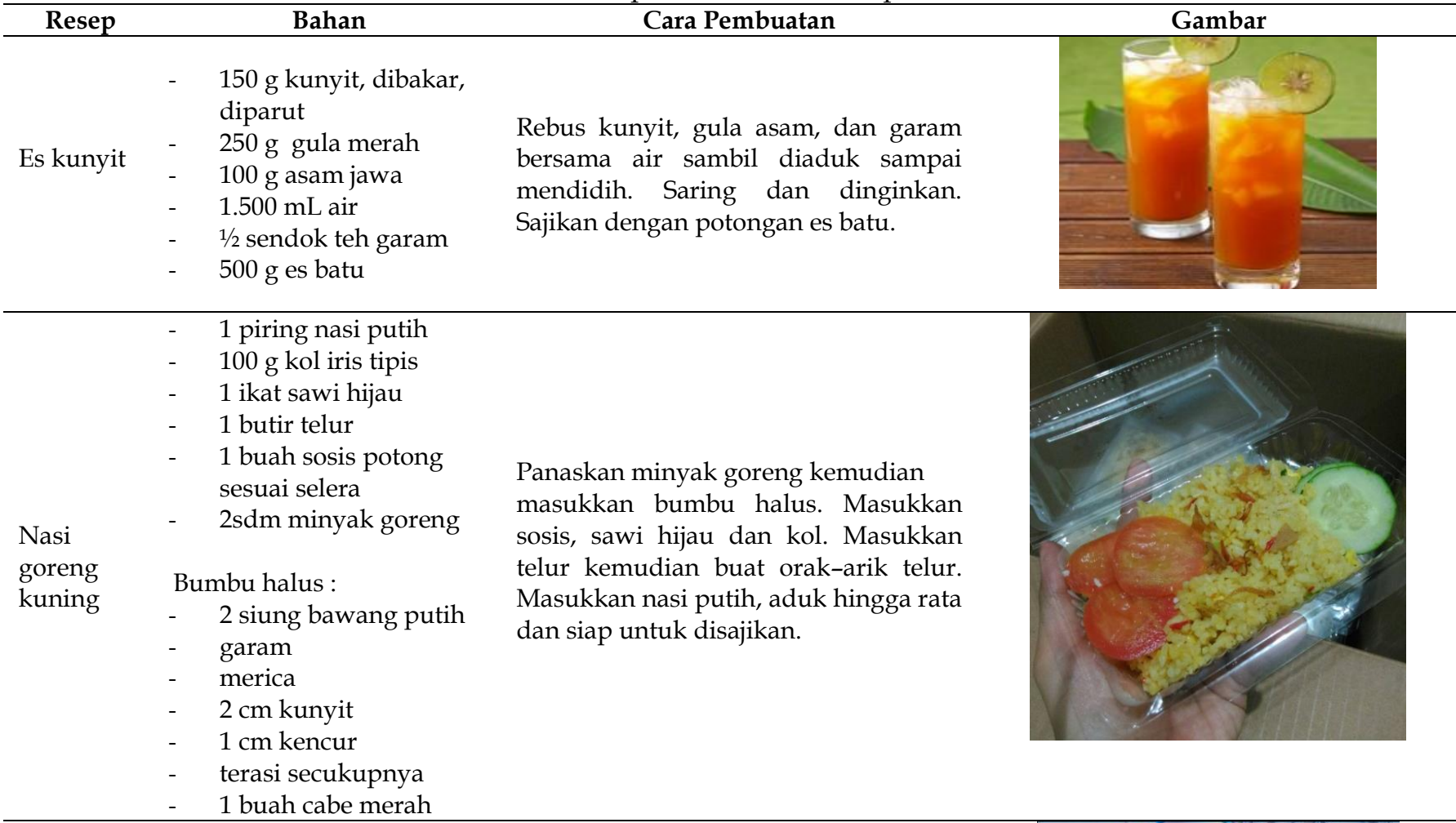

$\begin{array}{lll} & - & \text { Roti } 2 \text { lembar } \\ & - & \text { Telur } 1 \text { butir (didadar) } \\ \text { Sandwich } & - & \text { Tomat iris tipis } \\ \text { pandan } & - & \text { Mentimun iris tipis } \\ \text { telur } & - & \text { Saos sambal botol } \\ & - & \text { Keju parut } \\ & - & \text { Mentega secukupnya }\end{array}$

Oleskan mentega pada roti. Susun semua bahan diatas roti. Tutup menggunakan lembaran roti lainnya. Oleskan mentega diatasnya. Panaskan wajan, kemudian masukkan mentega Panggang roti sampai kecoklatan Sajikan dengan saos sambal dan mayonnaise

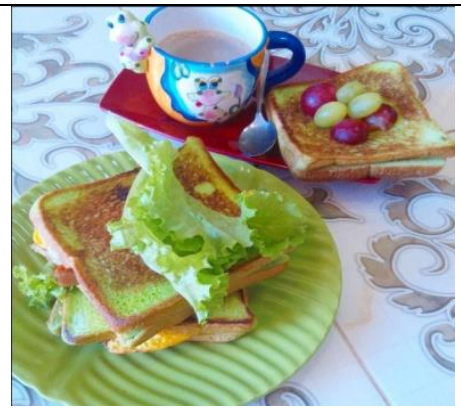

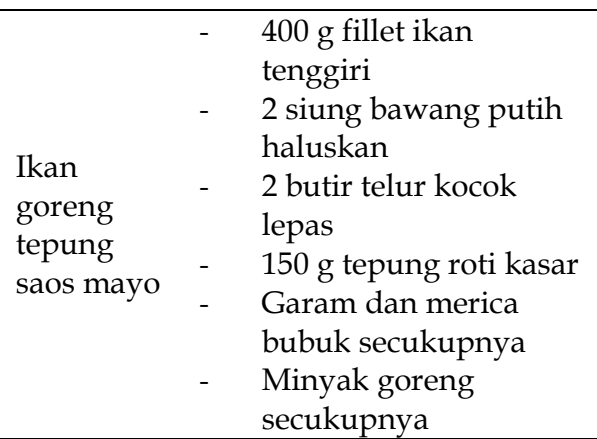

Lumuri fillet dengan bawang putih, garam dan merica bubuk hingga rata. Diamkan selam 15 menit hingga bumbu meresap. Celupkan fillet ikan ke dalam kocokan telur, gulingkan dalam tepung roti, lakukan pelapisan hingga dua kali. Goreng ikan hingga matang lalu angkat dan tiriskan. Sajikan dengan saos mayonnaise

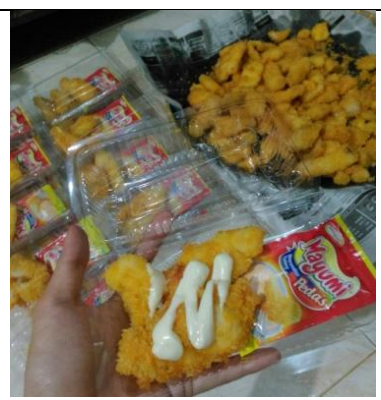

Evaluasi hasil inovasi memiliki tingkat penerimaan yang baik ditinjau dari rasa pada seluruh sasaran program terbukti dari jumlah penganan yang disajikan habis bahkan kurang untuk disediakan bagi sasaran program. Proses penyelesaian masalah tampak ketika orang tua dan guru banyak mengajukan pertanyaan terkait pembuatan menu, seperti alternatif penggunaan bahan ataupun cara memasak. Pemberian doorprize diberikan kepada sasaran yang berperan aktif dalam sesi tersebut.

Koordinasi lintas sektor terjalin antar program studi Farmasi UNRAM, Gizi UNU, MI Nurul Islam Sekarbela, dan masyarakat sebagai wali murid melalui kegiatan pengabdian masyarakat (Gambar 6). Hal ini sangat penting dalam kesuksesan program penggerakan sarapan sehat dan kepedulian akan penyediaaan PJAS yang memenuhi syarat. 


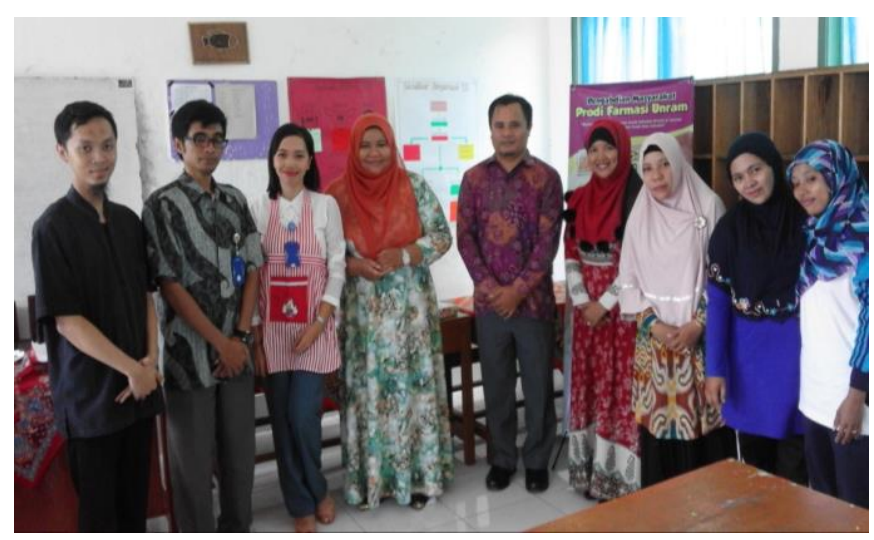

Gambar 6. Koordinasi lintas sektor dalam workshop.

\section{Simpulan}

Dari kegiatan pengabdian masyarakat yang telah dilaksanakan dapat disimpulkan bahwa penyuluhan dan pembimbingan secara terpadu dapat meningkatkan pengetahuan sasaran program dalam pemilihan PJAS yang memenuhi syarat serta mengaplikasikan pembuatan menu inovasi sarapan sehat praktis dan ekonomis.

Evaluasi program perlu ditingkatkan melalui indikator yang lebih terukur secara kuantitatif semisal melalui pemberian angket. Selain perlu dilakukan dalam cakupan yang lebih luas, identifikasi PJAS mandiri secara fisik dan kimia dengan melibatkan Balai Pengawas Obat dan Makanan perlu dilakukan dalam kegiatan pengabdian masyarakat selanjutnya sebagai bentuk peningkatan kepedulian pemerintah dan masyarakat terhadap surveilans keamanan PJAS.

\section{Ucapan Terima Kasih}

Ucapan terima kasih disampaikan kepada Kementerian Riset, Teknologi dan Pendidikan Tinggi atas pembiayaan pengabdian masyarakat yang berasal dari Bantuan Operasional Perguruan Tinggi Negeri (BOPTN).

\section{Daftar Pustaka}

Brown, J. L., Beardslee, W. H., \& Prothrow-Stith, D. (2008). Impact of school breakfast on children's health and learning: An analysis of the scientific research. Sodexo Foundation: Harvard, hal. 5.

Hardinsyah. (2013). Sarapan sehat salah satu pilar gizi seimbang: disampaikan pada Simposium Nasional Sarapan Sehat di Jakarta, 8 Januari 2013.

Kementerian Kesehatan RI. (2014). Peraturan Menteri Kesehatan Republik Indonesia No. 41 Tahun 2014 tentang Pedoman Gizi Seimbang. Kementerian Kesehatan RI: Jakarta, hal. 42-43.
Kementerian Kesehatan RI. (2015). Keputusan Menteri Kesehatan Republik Indonesia No. HK.02.02/MENKES/52/2015 tentang Rencana Strategis Kementerian Kesehatan Tahun 2015-2019. Kementerian Kesehatan RI: Jakarta, hal. 6.

Nirkomala. (2015). Menteri Yohana temukan kasus gizi buruk di Mataram. Antara News. Diakses dari http://www.antaranews.com/berita/522638 /menteri-yohana-temukan-kasus-gizi-buruk-dimataram

Pemerintah Provinsi Nusa Tenggara Barat. (2012). Peraturan Gubernur Nusa Tenggara Barat No. 11 Tahun 2012 tentang Rencana Aksi Daerah Pangan dan Gizi Provinsi Nusa Tenggara Barat Tahun 20112015. Pemerintah Provinsi Nusa Tenggara Barat: Mataram, hal. 23.

Sugihantono, A. (2014). Rencana strategis pembangunan kesehatan bidang gizi dan KIA: disampaikan pada Pertemuan Ilmiah dan Kongres PERSAGI XV di Yogyakarta, 26 November 2014. Direktorat Jenderal Bina Gizi dan KIA Kementerian Kesehatan RI: Jakarta, hal. 19, 24-25. 